\title{
Molecular and Physiological Characterization of Copper-Resistant Bacteria Isolated from Activated Sludge in an Industrial Wastewater Treatment Plant in Rungkut-Surabaya, Indonesia
}

\author{
WAHYU IRAWATI ${ }^{1}$, TRIWIBOWO YUWONO ${ }^{2}$, JOEDORO SOEDARSONO$^{2}$, \\ AND HARI HARTIKO ${ }^{3}$
}

\author{
${ }^{\prime}$ Department of Biology, Faculty of Science and Mathematics, Universitas Pelita Harapan, Jalan MH Thamrin Boulevard \\ 1100, Lippo Karawaci, Tangerang 15811, Indonesia; \\ ${ }^{2}$ Laboratory of Microbiology, Faculty of Agriculture, Universitas Gadjah Mada, \\ Sekip Unit I, Yogyakarta 55281, Indonesia; \\ ${ }^{3}$ Laboratory of Biochemistry, Faculty of Biology, Universitas Gadjah Mada, \\ Jalan Teknika Selatan, Yogyakarta 5528, Indonesia
}

\begin{abstract}
Copper resistant bacteria can be isolated from environments where copper levels are abundant from mining, industrial, or agricultural activities. The aim of this work was to study the molecular and physiological characteristics of indigenous copper resistant bacteria isolated from activated sludge in an industrial wastewater treatment plant in Surabaya, Indonesia. The bacterial isolates were designated as strains $\mathrm{IrC} 1, \mathrm{IrC} 2$, and $\mathrm{IrC} 4$. Phylogenetic analysis based on $16 \mathrm{~S}$ rDNA sequence analysis identified isolates $\operatorname{IrC} 1, \operatorname{IrC} 2$, and $\operatorname{IrC} 4$ as Acinetobacter oleivorans $(98.41 \%$ similarity), Acinetobacter pitii $(97.22 \%$ similarity), and Cupriavidus pauculus $\left(96.99 \%\right.$ similarity), respectively. The addition of $5 \mathrm{mM}$ of $\mathrm{CuSO}_{4}$ in the medium affected morphological appearance of all isolates to green and undulate margin might be due to the survival mechanism of bacteria by absorbing the copper. This studies indicated that copper resistance mechanism of all isolates was facilitated through the bioaccumulation of copper inside the cell, especially on the membrane fraction and inside the cytoplasm, albeit at a limited amount. It was observed that isolates $\mathrm{IrC} 1, \mathrm{IrC} 2$, and $\mathrm{IrC} 4$ were capable of accumulating $137.23,364.66$, and $272.07 \mathrm{mg} \mathrm{L}^{-1}$ of copper, respectively from the medium containing $8 \mathrm{mM}$ $\mathrm{CuSO}_{4}$. The capability of isolates $\mathrm{IrC} 1, \mathrm{IrC} 2$, and $\mathrm{IrC} 4$ to accumulate copper can be exploited in bioremediation process for removing copper from industrial sewage.
\end{abstract}

Key words : 16S rDNA, accumulation, bioremediation, copper-resistant bacteria, phylogenetic analysis

Bakteri resisten tembaga dapat diisolasi dari lingkungan yang terkontaminasi tembaga konsentrasi tinggi akibat aktivitas pertambangan, industri, maupun pertanian. Penelitian ini bertujuan untuk mempelajari karakterisasi fisiologis dan molekular bakteri resisten tembaga asli yang diisolasi dari lumpur aktif pengolahan limbah industri di Surabaya, Indonesia. Isolat bakteri diberi nama galur $\mathrm{IrC} 1$, $\operatorname{IrC} 2$, dan $\mathrm{IrC} 4$. Analisis filogeni berdasarkan analisis urutan basa gen $16 \mathrm{~S}$ rDNA mengidentifikasikan masing-masing isolat $\mathrm{IrC} 1, \operatorname{IrC} 2$, and $\operatorname{IrC} 4$ sebagai Acinetobacter oleivorans (kemiripan 98,41\%), Acinetobacter pitii (kemiripan 97.22\%), dan Cupriavidus pauculus (kemiripan 96,99\%). Penambahan $5 \mathrm{mM} \mathrm{CuSO}_{4}$ mengakibatkan perubahan morfologi koloni isolat bakteri menjadi hijau dengan tepi yang bergelombang diduga berkaitan dengan mekanisme pertahanan bakteri dengan cara mengabsorbsi tembaga. Hasil penelitian menunjukkan bahwa mekanisme resistensi isolat $\mathrm{IrC} 1$, IrC2, dan $\mathrm{IrC} 4$ terhadap tembaga adalah dengan cara mengakumulasi tembaga di dalam sel khususnya di bagian membran dan membatasi jumlah tembaga di dalam sitoplasma. Masing-masing isolat bakteri dapat mengakumulasi tembaga sebesar 137,23 $\mathrm{mg} \mathrm{L}^{-1}, 364,66 \mathrm{mg} \mathrm{L}^{-1}$, dan 272,07 $\mathrm{mg} \mathrm{L}^{-1}$ pada medium yang mengandung $8 \mathrm{mM} \mathrm{CuSO}_{4}$. Kemampuan isolat $\mathrm{IrC} 1, \mathrm{IrC} 2$, and $\mathrm{IrC} 4$ dalam mengakumulasi tembaga dapat dikembangkan dalam proses bioremediasi untuk memindahkan tembaga dari limbah industri.

Kata kunci : 16S rDNA, akumulasi, analisis filogeni, bakteri resisten tembaga, bioremediasi

The discharge of heavy metals into the environment as a result of agricultural, industrial and military operations, and the effects of this pollution on ecosystems and human health have been of concern for some years (Essa et al. 2002). Copper, one of the most widely used heavy metals, is mainly employed in electrical and

*Corresponding author; Phone: +62-21-5460901, E-mail: w.irawati3@gmail.com electroplating industries and in a larger amount is extremely toxic to living organisms. The presence of copper (II) ions cause serious toxicological concerns, as it is known to deposit in brain, skin, liver, pancreas and myocardium (Davis et al. 2000).

Copper cannot be destroyed and tends to accumulate in soils, plants, and animals, increasing their concentrations in the superior level of food chains. This metal has been shown to be toxic to 
vertebrata when contaminating dietary sources, usually in the range of 100-1000 $\mathrm{mg} \mathrm{L}^{-1}$ (Georgopoulus et al. 2001). Since heavy metals are found in microbial habitats due to natural and environmental processes, microbes have evolved several mechanisms to tolerate the presence of heavy metals (Adarsh et al. 2007). Metal-tolerant bacteria could survive in these habitats and could be isolated and selected for their potential application in bioremediation of contaminated sites (Piotrowska-Seget et al.2005).

Microorganisms and microbial products have been reported to efficiently remove soluble and particulate forms of metals, especially from dilute solutions, through bioaccumulation and therefore microbebased technologies provide an alternative to the conventional techniques of metal removal/recovery. Microbes are capable of accumulating toxic metal ions by two well defined processes, i.e.: (i) biosorption: an energy-independent binding of metal ions to cell walls, and (ii) bioaccumulation: energy-dependent process of metal uptake into the cells. Both live and inactivated microbial mass of bacteria, fungi and algae are utilized for removing toxic metal ions (Raja et al. 2006).

The bioremediation of heavy metals using microorganisms has received a great deal of attention in recent years, not only as a scientific novelty but also for its potential application in industry. Conventional techniques for removing dissolved heavy metals include chemical precipitation, carbon adsorption, electrolytic recovery, ion-exchange, chelation and solvent extraction or liquid membrane separationall exhibit several disadvantages, such as high cost, incomplete removal, low selectivity, high energy consumption and generation of toxic slurries that are difficult to be eliminated. Therefore, much attention has been paid to the removal of metal ions by microorganisms due to its potential applications in environmental protection and recovery of toxic heavy metals (Zaki and Farag 2010).

Isolation of bacteria from metal polluted environment would represent an appropriate practice to select metal resistant strains that could be used for heavy metal removal and bioremediation purposes (Malik 2004). Many indigenous organisms isolated from heavy metal contaminated sites had tolerance to heavy metals toxicity (Yong et al. 2008). Some reports have shown that indigenous microbes tolerate high heavy metal concentrations in different ways and may play a significant role in the restoration of contaminated site (Carrasco et al. 2005; Ge et al. 2009). It is important to study the indigenous microorganisms in heavy metal polluted sites. It may provide new insight into bacterial diversity under unfavorable conditions, new isolates and probably new genetic information on heavy metal resistance, which could be exploited in future for bioremediation (Fabienne et al. 2003). The aim of this work was to study the molecular and physiological characterization of indigenous copper resistant bacteria isolated from activated sludge in an industrial wastewater treatment plant in Surabaya, Indonesia.

\section{MATERIALS AND METHODS}

Bacteria and Growth media. Isolates $\mathrm{IrC} 1, \mathrm{IrC} 2$, and $\mathrm{IrC} 4$ were isolated from activated sludge in an industrial wastewater treatment plant in Rungkut, Surabaya, Indonesia. The bacterial isolates demonstrated highly copper resistance with Minimum Inhibitory Concentration (MIC) of $6 \mathrm{mM}$ to $7 \mathrm{mM}$ $\mathrm{CuSO}_{4}$. Bacteria were grown in Salt Base Solution (SBS) broth containing the following (per liter): $\mathrm{K}_{2} \mathrm{HPO}_{4} 1.5 \mathrm{~g} ; \mathrm{KH}_{2} \mathrm{PO}_{4} 0.5 \mathrm{~g}$; $\left(\mathrm{NH}_{4}\right)_{2} \mathrm{SO}_{4} 0.5 \mathrm{~g}$; $\mathrm{Mg}_{2} \mathrm{SO}_{4} \cdot 7 \mathrm{H}_{2} \mathrm{O} 0.2 \mathrm{~g}$, supplemented with appropriate concentration of copper sulfate, and in medium without copper (Irawati et al. 2003). Cells were incubated at $37{ }^{\circ} \mathrm{C}$ in a shaker $(200 \mathrm{rpm})$. Growth was monitored by measuring optical density at $600 \mathrm{~nm}$.

Phenotypic Characterization of Copper Resistant Bacteria. Phenotypic characterization was conducted to analyze bacterial cell morphology, biochemical properties, and the ability to grow at various temperature (Capuccino and Sherman 2005). Biochemical characterization included ulitization of catalase, oxidase and citrate, $\mathrm{H}_{2} \mathrm{~S}$ production, and hydrolysis of gelatin. Tests of the bacterial ability to use different sugars as a carbon source were also conducted; these included glucose, arabinose, lactose, sucrose, galactose, D-xilose, trehalose, melibiose, Dmannosa, D-manitol, D-sorbitol, inositol, and glycerol. The bacterial isolates were tested for their abblility to grow on SBS medium agar at various temperature (4, 25 , and $37^{\circ} \mathrm{C}$ ).

Phylogenetic Characterization of Copper-resistant Bacteria. Pure culture of the target bacteria was grown overnight in SBS broth medium for the isolation of genomic DNA by using the method of spooling with a glass rod as described by Zyskind and Bernstein (1992) and $16 \mathrm{~S}$ rDNA was amplified by using the universal bacterial 16S rDNA primers. The 16S rDNA region was PCR-amplified using the following primer set: 5'TGGCTCAGAACGAACGAACGCTGGCGGC-3' 
(position 20 to 43 of the Escherichia coli 16S rRNA genes) and 5'-TACCTTGTTACGACTTCACCCCAGTG-3' (position 1482 to 1507 of the E. coli $16 \mathrm{~S}$ rRNA genes). The PCR mixture $(25 \mu \mathrm{L})$ contained $1 \mu$ t template, $2.5 \mu \mathrm{L}$ of 10x Taq DNA polymerase buffer, $3.5 \mathrm{mM} \mathrm{MgCl}_{2}, 5 \mu \mathrm{L}$ of dNTP at $1 \mathrm{mM}, 1,25 \mu \mathrm{L}$ primers (each) at $10 \mu \mathrm{M}$, and $0.2 \mu \mathrm{L}$ of $0.2 \mu \mathrm{L} 5 \mathrm{U}$ Taq polymerase. The PCR was performed in a DNA Engine Thermal Cycler (PTC-200, BIO-RAD, USA) with a hot start performed at $95^{\circ} \mathrm{C}$ for 3 min, followed by 30 cycles of $94{ }^{\circ} \mathrm{C}$ for $1 \mathrm{~min}, 59^{\circ} \mathrm{C}$ for 1 min, and $72{ }^{\circ} \mathrm{C}$ for $2 \mathrm{~min}$, followed by a final extension performed at $72{ }^{\circ} \mathrm{C}$ for $3 \mathrm{~min}$. PCR products were analyzed by electrophoresis on $1.5 \%(\mathrm{w} / \mathrm{v})$ agarose gel in 1x TAE buffer supplemented with ethidium bromide ( 0.5 $\left.\mu \mathrm{g} \mathrm{L}^{-1}\right)$. Sequencing was performed at Eijkman Molecular Biology Institute (Jakarta, Indonesia). The 16S rDNA sequence was compared against the GenBank database as described in http://eztaxon-e.ezbiocloud.net/. Based on the scoring index, the most similar sequences were aligned with the sequences of other representative bacterial $16 \mathrm{~S}$ rDNA regions by using Clustal X software. Phylogenetic tree was constructed by using neighbor-joining tree analysis. A consensus tree was generated using MEGA 5.1 software (Molecular Evolutionary Genetics Analysis) (downloaded from www.megasoftware.net).

Cellullar Fractionation and Copper Accumulation. For determination of the copper content of fractions of bacterial cells, copper content of bacterial cells were determined according to the method of Cha and Cooksey (1991) with some modifications. Cells were grown in SBS broth containing $8 \mathrm{mM}$ of $\mathrm{CuSO}_{4}$ and incubated at $37^{\circ} \mathrm{C}$ with shaking at $200 \mathrm{rpm}$. Cells were collected in an appropriate phase of bacterial growth by centrifugation at $5000 \mathrm{x}$ g for $20 \mathrm{~min}$ at $4{ }^{\circ} \mathrm{C}$ and washed several times with copper-free phosphate buffer. Cells were suspended with $10 \mathrm{~mL} 30 \mathrm{mM}$ Tris- $\mathrm{HCl} \mathrm{pH} 8$ containing $0.2 \mathrm{mg}$ of DNAse I and $0.2 \mathrm{mg}$ of RNAse, and sonicated for $20 \mathrm{sec}$ at $100 \mathrm{~W}$. The lysate was incubated with $1 \mathrm{mg}$ of lysozyme for $30 \mathrm{~min}$ at room temperature and ultracentrifuged at $77600 \mathrm{x}$ g for $2.5 \mathrm{~h}$ to separate cytoplasmic fractions in the supernatant from the pellet of cell membrane fraction. The pellet was suspended in $10 \mathrm{~mL}$ of water. The pellet and the supernatant was separately disrupted with $\mathrm{HNO}_{3}$ at 100 ${ }^{\circ} \mathrm{C}$. Copper content was determined by using atomic absorption spectrophotometer at $324.9 \mathrm{~nm}$. Copper content of the whole cell was also determined. Bacterial cells from the same cultures were freezedried for determination of dry weight and total copper content.

\section{RESULTS}

\section{Phenotypic Characterization of Copper Resistant}

Bacteria. Phenotypic characteristics of isolates $\mathrm{IrCl}$, $\mathrm{IrC} 2$, and $\mathrm{IrC} 4$ are given in table 1. All three isolates were Gram negative and rod shape motiled bacteria. For all isolates, there was catalase activity and there was no oxidase activity. $\mathrm{H}_{2} \mathrm{~S}$ production and citrate utilization were negative for all isolates. Hidrolysis of gelatin was detected for all isolates. All isolates grew at 4, 25, and 37 ${ }^{\circ} \mathrm{C}$. Isolate $\mathrm{IrC} 1$ had ability to produce acid from oxidation or fermentation of glucose, L-arabinose, lactose, melibiose, D-mannose, galactose, and D-Xylose. Meanwhile, isolates $\mathrm{IrC} 2$ and $\mathrm{IrC} 4$ were incapable of producing acid from oxidation or fermentation of glucose, arabinose, lactose, sucrose, galactose, D-xilose, trehalose, melibiose, D-mannosa, D-manitol, D-sorbitol, inositol, and glycerol. When all isolates were grown on SBS agar, colonies of the bacterial isolates were whiteopaque, light yellow-tanslucent, and white-translucent, respevtively. It was shown that the colonies of all isolates turned blue when they were grown on SBS agar containing high concentration of copper (Fig 1). The presence of high copper concentration also affected the appearance of the colony margin to undulate (Fig 2).

Phylogenetic Characterization of Coperresistant Bacteria. Phylogenetic analysis based on 16S rDNA sequence analysis identified isolates $\mathrm{IrC} 1$, $\mathrm{IrC} 2$, and $\mathrm{IrC} 4$ as Acinetobacter oleivorans $(98.41 \%$ similarity), Acinetobacter pitii (97.22\% similarity), and Cupriavidus pauculus (96.99\% similarity), respectively (Table 1). Comparative analysis of the sequences with the available database showed that the isolates $\mathrm{IrC} 1$ and $\mathrm{IrC} 2$ were close to the members of genus Acinetobacter, meanwhile isolate $\mathrm{IrC} 4$ was close to the members of genus Cupriadivus (Fig 3). The nucleotide sequence data of isolates $\operatorname{IrC} 1, \operatorname{IrC} 2$, and IrC4 have been deposited in the NCBI nucleotide sequence database (GenBank) under the accession number of JX009133, JX009134, and JX398287, respectively.

Copper Accumulation. It was shown in this study that copper resistance mechanism of the isolates was facilitated through the accumulation of copper on the cell. The results of copper accumulation on the whole cell, membrane fraction and cytoplasm showed that copper resistance mechanism in the bacterial isolates involves accumulation of this metal especially on the membrane fraction and restricts amount of copper inside the cytoplasm up to 40.37-57.6 $\mathrm{mg} \mathrm{L}^{-1}$ (Fig 4). The highest amount of copper accumulated by isolates $\mathrm{IrC} 1, \mathrm{IrC} 2$, 
Table 1 Phenotypic characteristics of copper-resistant bacteria

\begin{tabular}{|c|c|c|c|}
\hline Bacterial isolates & Strain $\mathrm{IrCl}$ & Strain $\mathrm{IrC} 2$ & Strain IrC4 \\
\hline \multicolumn{4}{|l|}{ Morphological } \\
\hline Colony color & White & Light yellow & White \\
\hline Gram staining & Negative & Negative & Negative \\
\hline Cell morphology & Rod & Rod & Rod \\
\hline motility & + & + & + \\
\hline \multicolumn{4}{|l|}{ Biochemical } \\
\hline Catalase & + & + & + \\
\hline Oxidase & - & - & - \\
\hline Pigmentation & - & - & - \\
\hline $\mathrm{H}_{2} \mathrm{~S}$ production & - & - & - \\
\hline Gelatin agar test & - & - & - \\
\hline \multicolumn{4}{|l|}{ Utilization of } \\
\hline Glucose (acid) & + & - & - \\
\hline Glucose (gase) & - & - & - \\
\hline $\mathrm{KCN}$ & - & - & - \\
\hline Citrate & - & - & - \\
\hline \multicolumn{4}{|l|}{ Utilization of } \\
\hline L-arabinose & + & - & - \\
\hline Lactose & + & - & - \\
\hline Sucrose & - & - & - \\
\hline Galactose & + & - & - \\
\hline D-Xilose & + & - & - \\
\hline Trehalose & - & - & - \\
\hline Melibiose & + & - & - \\
\hline D-mannose & + & - & - \\
\hline D-manitol & - & - & - \\
\hline D-sorbitol & - & - & - \\
\hline Inositol & - & - & - \\
\hline Glicerol & - & - & - \\
\hline \multicolumn{4}{|l|}{ Growth at : } \\
\hline $4{ }^{\circ} \mathrm{C}$ & + & + & + \\
\hline $25{ }^{\circ} \mathrm{C}$ & + & + & + \\
\hline $30{ }^{\circ} \mathrm{C}$ & + & + & + \\
\hline
\end{tabular}

Table 2 Copper-resistant bacterial strain isolated from activated sludge in an industrial wastewater treatment plant in Surabaya, Indonesia. Bacterial strains were identified based on the $16 \mathrm{~S}$ rDNA sequencing analysis

\begin{tabular}{|c|c|c|c|c|}
\hline Strain & Accession number & Length (bp) & $\begin{array}{c}\text { Species } \\
\text { most related }\end{array}$ & $\begin{array}{c}\text { Sequence Similarity } \\
(\%)\end{array}$ \\
\hline $\mathrm{IrC} 1$ & JX009133 & 1389 & $\begin{array}{l}\text { Acinetobacter } \\
\text { oleivorans }\end{array}$ & 98.41 \\
\hline $\mathrm{IrC} 2$ & JX009134 & 1371 & Acinetobacter pittii & 97.22 \\
\hline $\mathrm{IrC} 4$ & JX398287 & 612 & Cupriavidus pauculus & 96.99 \\
\hline
\end{tabular}

IrC4 was 137.23, 364.66, and $272.07 \mathrm{mg} \mathrm{L}^{-1}$ in the medium containing $8 \mathrm{mMCuSO}_{4}$, respectively.

\section{DISCUSSION}

Isolates $\mathrm{IrC} 1, \mathrm{IrC} 2$, and $\mathrm{IrC} 4$ were highly copperresistant bacteria isolated from activated sludge in an industrial wastewater treatment plant in RungkutSurabaya, Indonesia with $\mathrm{MIC}$ of 6-7 $\mathrm{mM} \mathrm{CuSO}_{4}$
(Irawati et al. 2002; Irawati et al. 2003). Phylogenetic analysis based on $16 \mathrm{~S}$ rDNA sequence analysis identified isolates $\mathrm{IrC} 1$, $\operatorname{IrC} 2$, and $\mathrm{IrC} 4$ as $A$. oleivorans (98.41\% similarity), A. pitii (97.22\% similarity), and C. pauculus (96.99 similarity), respectively (Table 1). The $16 \mathrm{~S}$ rDNA gene sequence analysis identified isolates $\mathrm{IrC} 1$ and $\mathrm{IrC} 2$ as strain of Acinetobacter sp. Meanwhile, isolate IrC4 has the possibility to be a novel species of the genus 


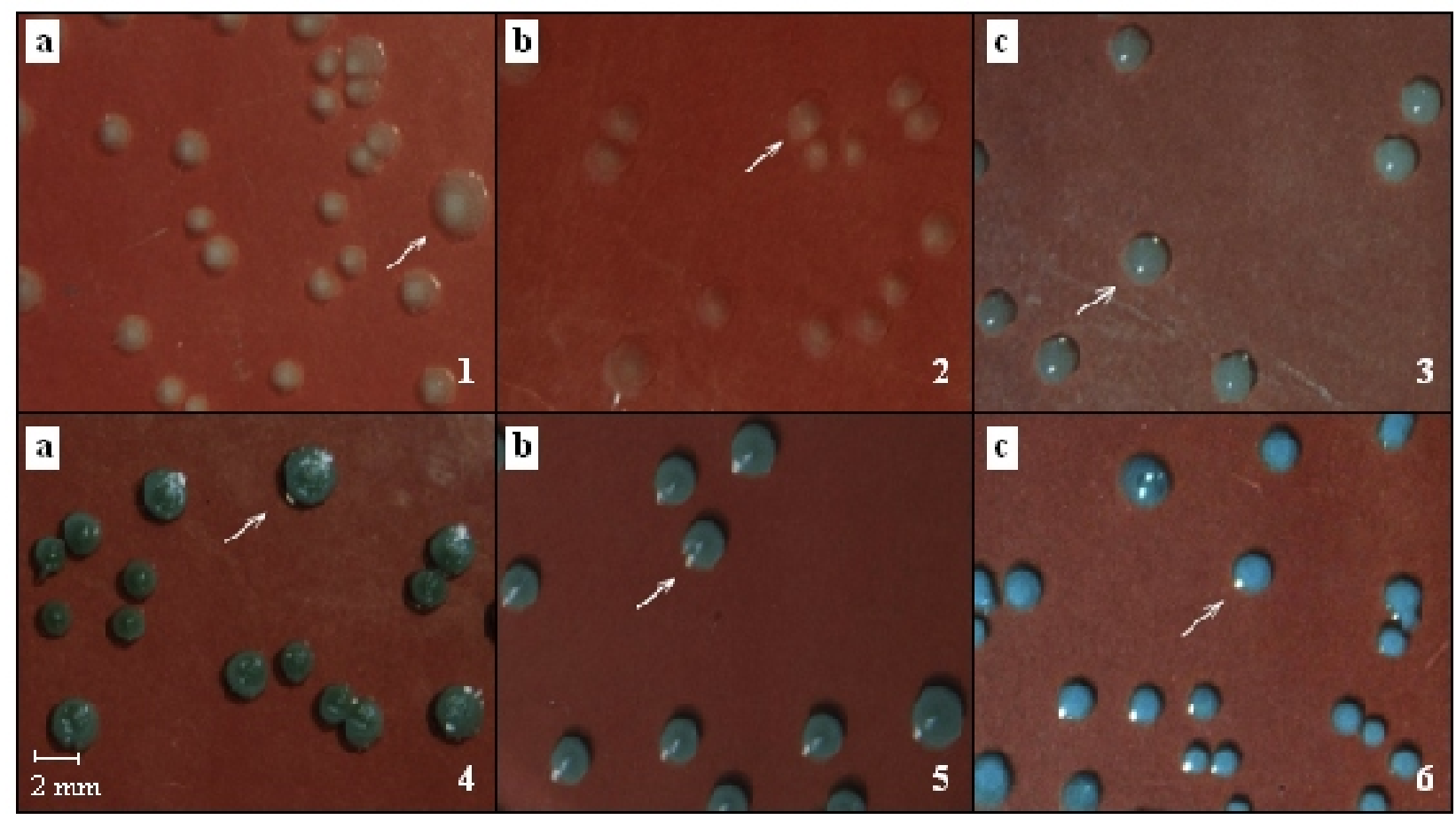

Fig 1 Colony morphologies of copper-resistant bacteria. (1a, 2b, 3c = Isolates $\operatorname{IrC} 1$, IrC2, IrC4 on medium without copper, respectively. 4a, 4b, 4c = Isolates $\mathrm{IrC} 1$, $\mathrm{IrC} 2$, IrC4 isolates on medium containing $5 \mathrm{mM} \mathrm{CuSO}_{4}$, respectively). Arrows showed the difference in colony color.

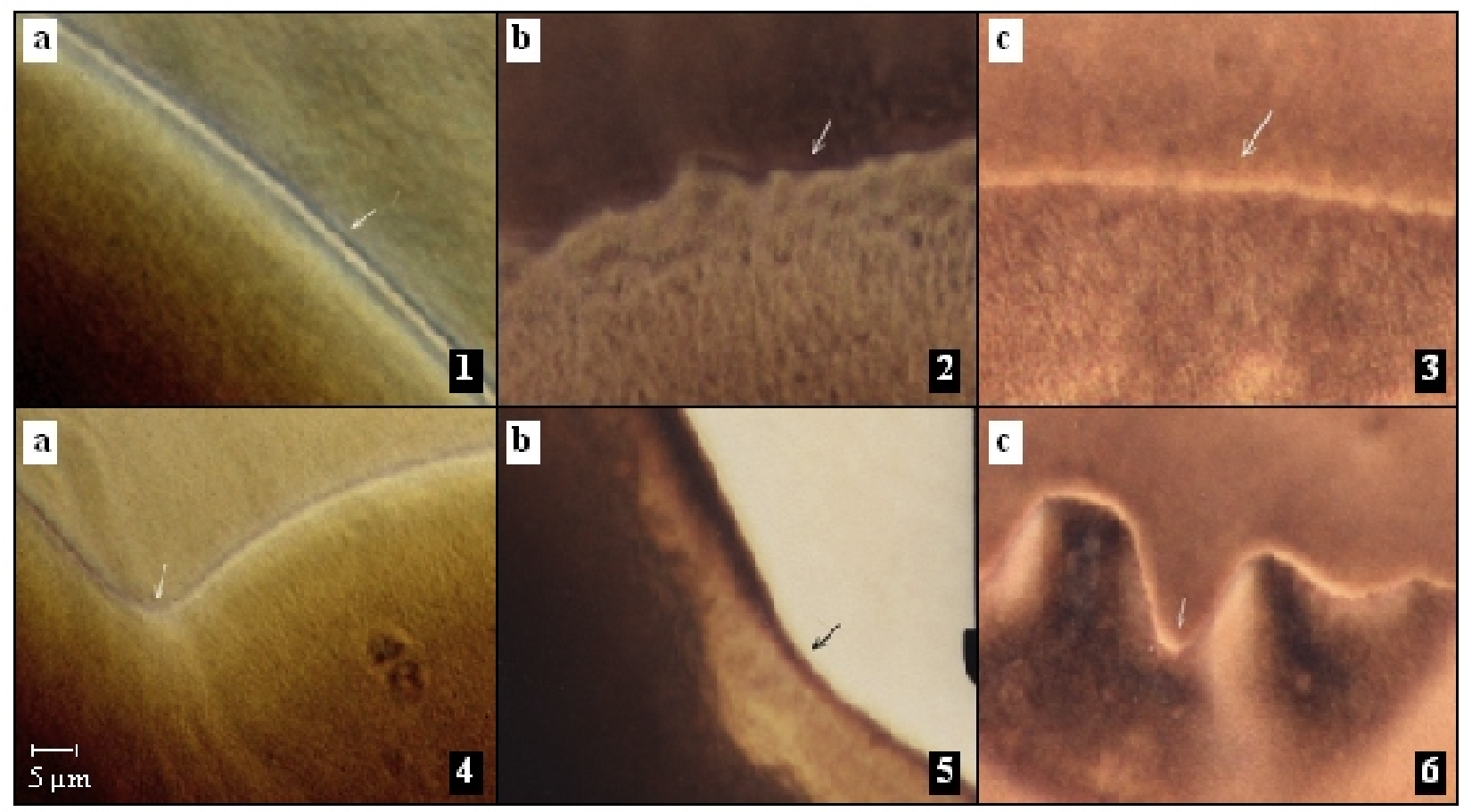

Fig 2 Micrograph of colonies margin on copper-resistant bacteria. (1a, 2b, 3c = IrC1, $\operatorname{IrC} 2$, IrC4 isolates on medium without copper, respectively. $4 \mathrm{a}, 4 \mathrm{~b}, 4 \mathrm{c}=\mathrm{IrC} 1$, IrC2, IrC4 isolates on medium containing $5 \mathrm{mM} \mathrm{CuSO}_{4}$, respectively). Colony margins were observed by phase contrast microscopy at 1000 times of magnification. Arrows showed the defference of colony margin.

Cupriavidus due to their 16S rDNA gene sequence similarities below 97\%, the threshold recognized as delineating a genospecies (Tindall et al. 2010). The genus Acinetobacter is known for its ability to survive a wide range of atmospheric and environmental conditions (Gusten et al. 2002; Simor et al. 2002; Jawad et al. 2004). In comparison with other bacteria, Acinetobacter is most consistently observed in the environment. Acinetobacter species are important biotechnological tools, and have been utilized 


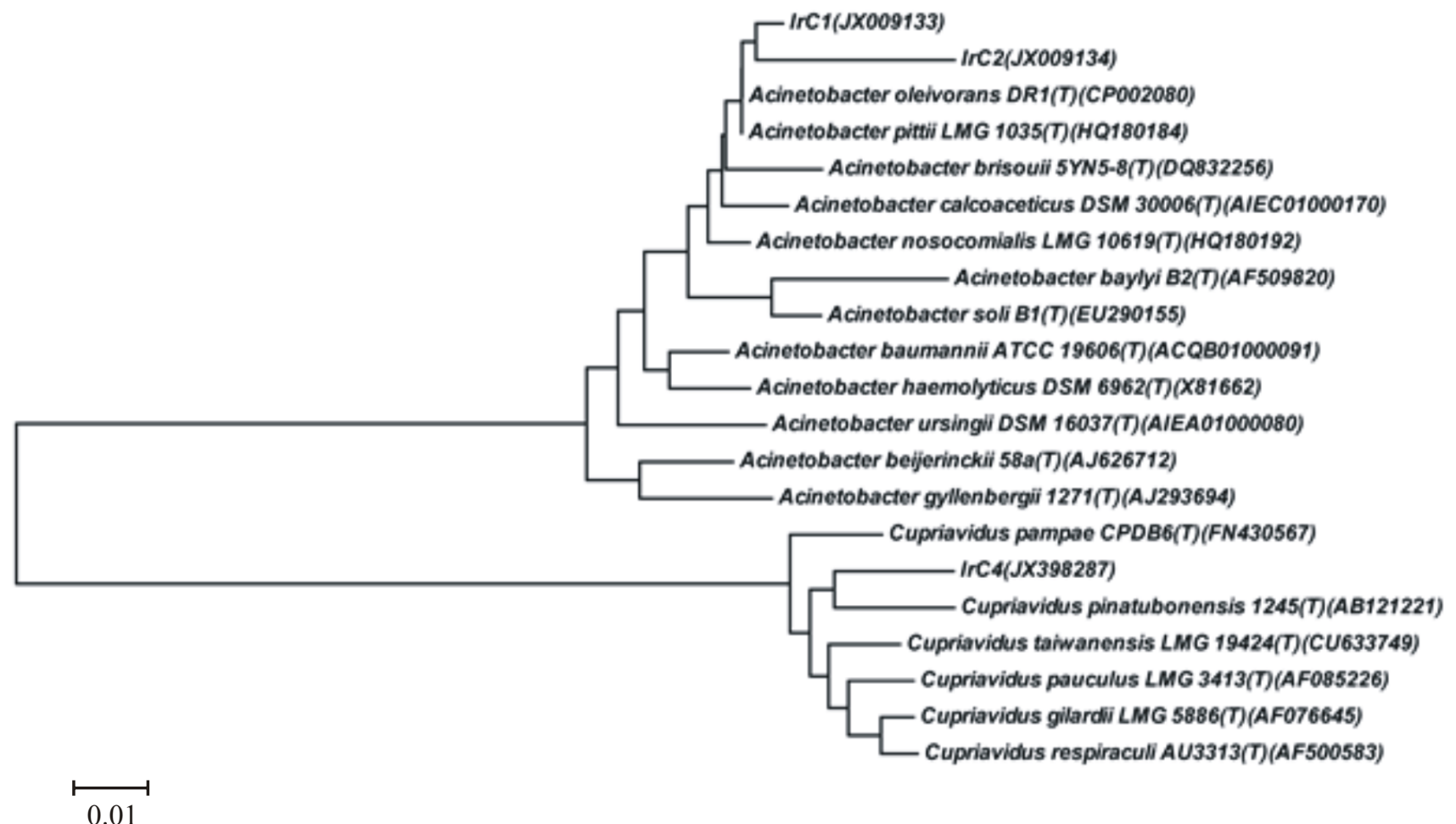

Fig 3 Phylogenetic tree of strains $\mathrm{IrC} 1$, IrC2, and $\mathrm{IrC} 4$ based on 16S rDNA gene sequences. GenBank accession numbers are given in parenthesis. Bar, 1 substitutions per 100 nucleotides.

extensively in the synthesis of enzymes and other lifesustaining macromolecules and for degradation of recalcitrant compounds (Chan et al. 2011). The genus Cupriavidus (formerly Ralstonia) is known as bacterium that contains a high number of heavy metal resistance genes making it an interesting model organism to study microbial responses to heavy metals (Mergeay et al.2003). C. pauculus has been reported as nickel resistant bacterium isolated from the rhizosphere of Rinorea bengalensis (Wall.), metalpercolated ultramafic ecosystem of Andaman, India (Pal and Paul 2010).

Bacteria exposed to a high level of heavy metals have adapted to this stress by employing various resistant mechanism (Ahmed et al. 2005). It is shown in this study that copper resistance mechanism in isolates $\mathrm{IrC} 1, \mathrm{IrC} 2$, and $\mathrm{IrC} 4$ involves accumulation of this metal especially on the membrane fraction and restricts amount of copper inside the cytoplasm. The highest amount of copper accumulated by isolates IrC1, IrC2, IrC4 was $137.23,364.66$, and $272.07 \mathrm{mg} \mathrm{L}^{-1}$, respectively, in the medium containing $8 \mathrm{mM} \mathrm{CuSO}_{4}$, respectively. Copper tolerance and bioaccumulation has been studied in bacteria-(Shakoori and Muneer 2002). The ability of the isolates to accumulate copper was higher than previously known copper-resistant bacteria. Two highly resistant strains of Pseudomonas syringae accumulated up to 115 to $120 \mathrm{mg}$ of copper per g dry weight of cells (Cooksey and Azad 1992), while Bacillus sp. strain CUR21 accumulated $\mathrm{Cu}$ of only $0.279 \mathrm{mg} \mathrm{g}^{-1}$ biomass (Kunito et al. 1997).

Copper binding on the cytoplasm of the isolates would seem to be saturated, which might be due to the delivery of copper ions to membrane fraction (Fig 4). Copper in its ionic form is a required trace element for most pro- and eukaryotic organisms, including human. While required in a small amount, copper can easily become toxic if present in an excessive amount. This toxicity is caused mainly due to the intrinsic properties of copper, as free copper ions undergo redox cycling reactions alternating between $\mathrm{Cu}(\mathrm{I})$ and $\mathrm{Cu}$ (II). This also results in the transfer of electrons to hydrogen peroxide and the concomitant generation of hydroxyl radicals that readily attack and damage cellular biomolecules. Recently, it was found that the majority of copper stress in E. coli, as indicated by hydroxyl radical formation, occurs within the periplasm, away from the cytoplasmic DNA, and is thus coppermediated oxidative stress (Macomber et al. 2007). The cytoplasm might thus be better protected from coppermediated oxidative stress, and indeed cells usually prevent accumulation of significant intracellular concentrations of free copper ions (Magnani et al. 2008). Moreover, free copper causes a depletion of the 
A

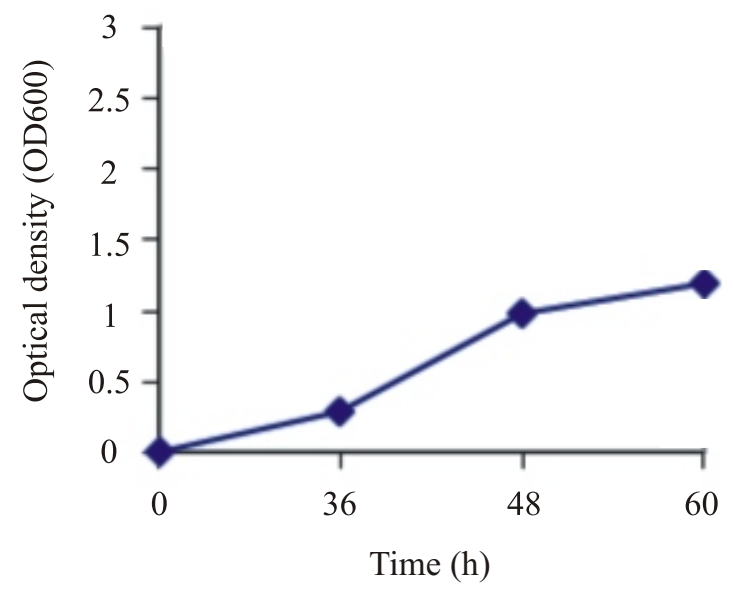

B

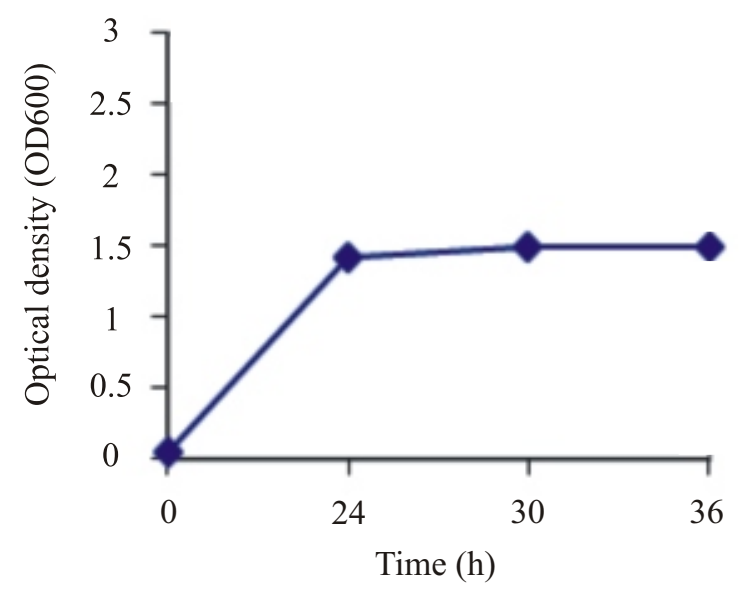

$\mathrm{C}$

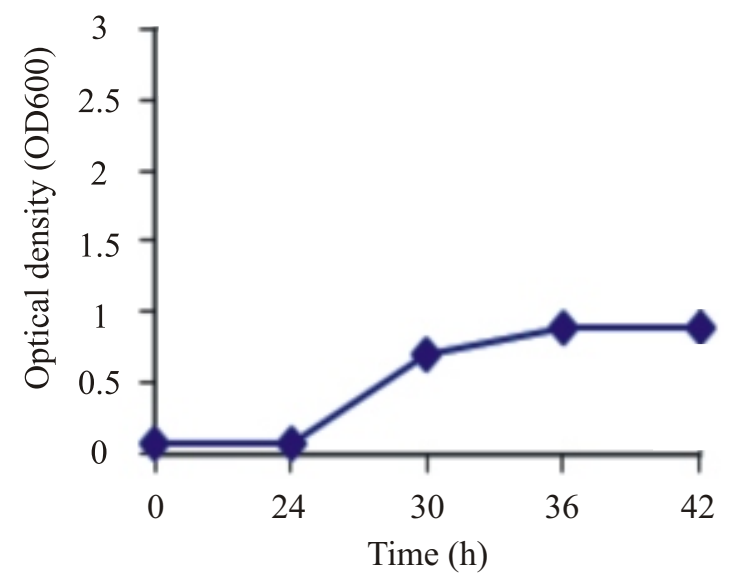

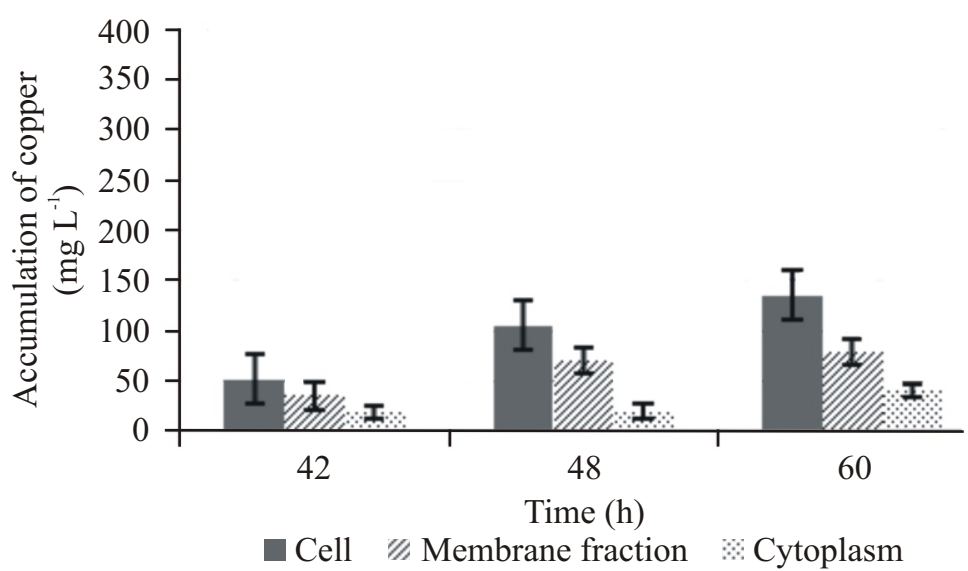

2

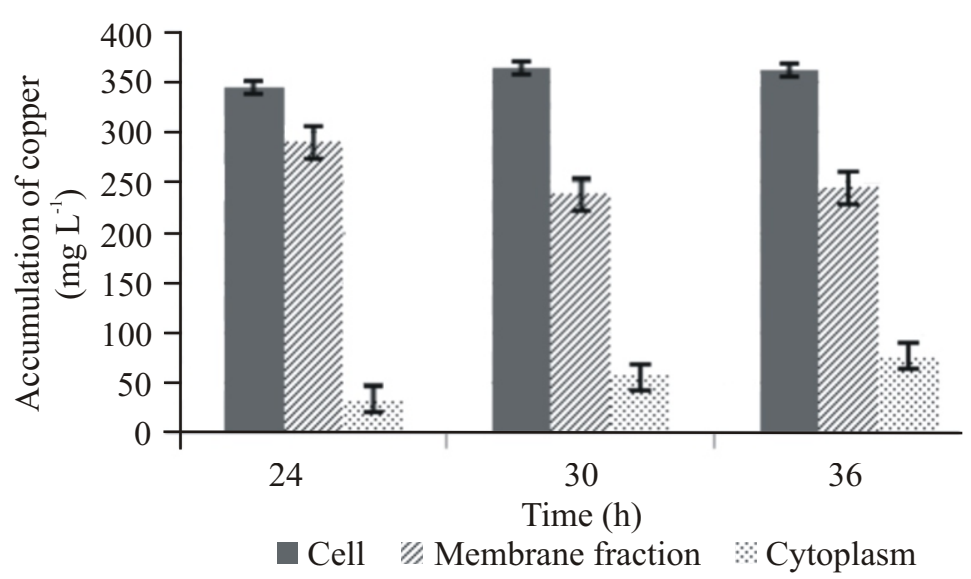

3

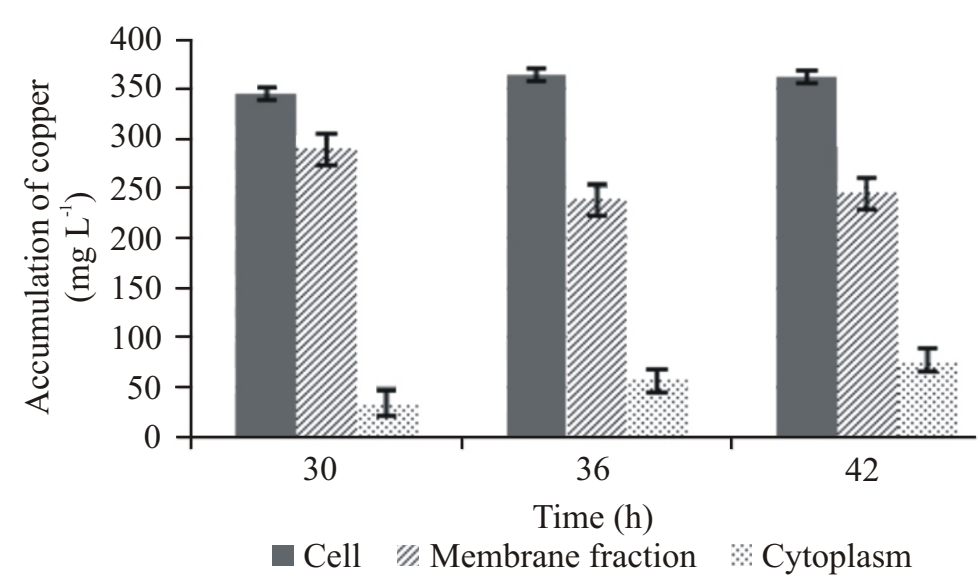

Fig 4 Growth and copper accumulation of copper-resistant isolates in medium containing $8 \mathrm{mM} \mathrm{CuSO}_{4}$. $(\mathrm{A}, \mathrm{B}, \mathrm{C}=$ growth of $\operatorname{IrC} 1, \operatorname{IrC} 2$, and $\operatorname{IrC} 4$, respectively. 1, 2, 3 = copper accumulation of $\operatorname{IrC} 1, \operatorname{IrC} 2$, and $\operatorname{IrC} 4$, respectively. Bars represent standard deviations (error bars) from three independent experiments.

cellular sulhydryl pool causing a pronounced decrease in cellular viability (Hiniker et al. 2005). The mechanisms of injury have forced bacteria to evolve different systems to tightly control intracellular copper level in order to counter the cation toxic effect (Osman and Cavet 2008; Waldron and Robinson 2009). The 
level of free copper within a cell must be limitted, and the transport of copper into cells and its transfer to copper-requiring enzymes needs to be highly regulated (Saxena et al. 2002).

Copper ions within the cytoplasm cause enzyme damage (Macomber and Imlay 2009). Free copper ions participate in redox reactions that generate hydroxyl radicals, which are highly reactive species that cause lipid peroxidation, nucleic acid cleavage, and protein damage. As such, virtually all cells have developed sophisticated homeostatic mechanism to tightly control copper uptake and its mobilization to appropriate target proteins and compartments. To ensure that sufficient copper is acquired to drive essential biochemical reactions yet prevent accumulation to levels that encourage harmful redox chemistry, cells homeostatically control copper via dedicated proteins that facilitate copper uptake, distribution, and efflux. These homeostatic mechanisms are regulated through cellular copper sensing mechanisms that operate at the level of gene transcription, protein stability, and trafficking (Puig et al. 2002).

Cha and Cooksey (1991) suggested that copper resistance could be the simple sequestration of copper ions in the periplasm, which prevents the entry of the toxic copper ions into the cytoplasm. Although $\mathrm{Cu}^{2+}$ is an essential micronutrient for most organisms, it exerts several toxic consequences above a threshold concentration. Therefore, microbes have to evolve strategies to restrict the intrasellular $\mathrm{Cu}^{2+}$ to a non-toxic limit. Cooksey (1994) reported that resistance against copper in $P$. syringae was because of the copper accumulation and compartmentalization in the cell's periplasm and the outer membrane and concluded that the protective mechanism against copper in P. syringae was due to four types of proteins (CopA, CopB, CopC, and CopD). These proteins are encoded by the cop operon present on bacterial plasmid and proteins are found in the periplasm (CopA and CopC), the outer membrane (CopB), and the inner membrane and work together to compartmentalize copper away from bacterial cells.

The addition of copper sulfate in the medium resulted in the greenish and undulate morphology of isolates $\operatorname{IrC} 1$, $\operatorname{IrC} 2$, and $\operatorname{IrC} 4$. Morphological changes of the colony to green and undulate might be due to the survival mechanism of bacterial isolates facilitated through the accumulation of copper. It was previously reported that copper-resistant strains of $P$. syringe pathovar tomato accumulate copper and develop blue colonies on copper-containing media. The mechanism of copper resistance in $P$. syringae is dependent on copper sequestration and accumulation in the periplasm and outer membrane (Cha dan Cooksey 1991; Puig et al. 2002). Similar result was described in Burkholderia, Alcaligenes, and Methylobacterium species in which the ratio of green colonies for sorbing $\mathrm{Cu}$ increased with the increasing of $\mathrm{Cu}$ content of the medium (Kunito et al. 1997). According to Rouch et al. (1985) though copper is one of the toxic heavy metals for soil bacteria, it is also an essential nutrient cation at a trace level. Thus a bacteria needs a mechanism to accumulate trace $\mathrm{Cu}$ as well as a $\mathrm{Cu}$-resistance system. Resistance by sequestration of this ion could be a more efficient mechanism to allow further growth of the bacteria in the presence of copper (Cha and Cooksey 1991).

The ability of microbial strain to grow in the presence of heavy metals would be beneficial in the waste water treatment where microorganisms are directly involved in the decomposition of organic matter in biological processes for waste water treatment, because often the inhibitory effect of heavy metals is a common phenomenon that occurs in the biological treatment of waste water and sewage (Filali et al. 2000). Isolates $\operatorname{IrC} 1, \operatorname{IrC} 2$, and $\mathrm{IrC} 4$ developed resistance mechanism by accumulating copper and protect itself from toxic concentration of copper ions while still ensuring that these ions met their nutritional requirements. These mechanism could be utilized for detoxification and removal of heavy metals from polluted environment. Such copper resistant bacterial are very useful in biotechnology for the remediation of metal contaminated environments and can also be used in the construction of biomarkers for detection of the presence of metals.

\section{ACKNOWLEDGMENTS}

This research was funded by University Research for Graduate Education (URGE), The SEARCA Thesis Grant, and the Habibie Center Thesis Grant.

\section{REFERENCES}

Adarsh VK, Mishra M, Chowdhury S, Sudarshan M, Thakur AR, Ray CS. 2007. Studies on metal microbe interaction of three bacterial isolates from east Calcuta wetland, Onlone. J Biol Sci. 7(2): 80-88. doi: 10.3844/ojbsci.2007.80.88.

Ahmed N, Nawaz A, Badar U. 2005. Screening of copper tolerant bacterial species and their potential to remove copper from the environment. Bull Environ Contam Toxicol. 74(2): 219-226. doi: 10.1007/s00128-004-0573-Z. 
Cappucino JG, Sherman N. 2005. Microbiology: A Laboratory Manual. Massachusetts: Addison-Wesley Publishing Company. p81-86.

Carrasco JA, Armario P, Pajuelo E, Burgos A. 2005. Isolation and characterization of symbiotically effective rhizobium resistant to arsenic and heavy metals after the toxic spill at the Aznalcollar pyrite mine. Soil Biol Biochem. 27(6): 1131-1140. doi:10.1016/j.soilbio.2004.11.015.

Cha J-S, Cooksey DA. 1991. Copper resistance in Pseudomonas syringae mediated by periplasmic and outer membrane proteins. Pro Nat Acad Sci. USA. 88(10) : 8915-8919. doi: 10.1073/pnas.88.20.8915

Chan KG, Atkinson S, Mathee K, Koh CL, William P. 2011. Characterization of $\mathrm{N}$-acylhomoserine lactonedegrading bacteria associated with Zingiber officinale (ginger) rhizosphere: Co-existence of quorum quenching and quorum sensing in Acinetobacter and Burkholderia. BMC Microbiol. p11:51. doi: 10.1186/1471-2180-11-51.

Cooksey DA, Azad HR. 1992. Accumulation of copper and other metals by copper resistant plant pathogenic and saprophytic Pseudomonas. Appl Environ Microb. 58(1): 274-278.

Cooksey DA. 1994. Molecular mechanisms of copper resistance and accumulation in bacteria. FEMS Microbiol Rev. 14(4): 381-386. doi: 10.1111/j.15746976.1994.tb00112.x

Davis JA, Volesky B, Vierra RHSF. 2000. Sargassum seaweed as biosorbent for heavy metals. Water Res. 34(17):42704278. doi: 10.1016/S0043-1354(00)00177-9.

Essa AMM, Macaskie LE, Brown NL. 2002. Mechanisms of mercury bioremediation. Biochemical Soc Transaction. 30(4):672-674. doi: 10.1042/BST0300672

Fabienne G, Antonis C, Hauke H. 2003. Comparative 16S rDNA and and 16S rRNA sequence analysis indicates that Actinobacteria might be a dominant part of the metabolically active bacteria in heavy metal contaminated bulk and rhizosphere soil. Environ Microbiol. 5(10): 896-907. doi:10.1046/j.14622920.2003.00484.x.

Filali BK, Taoufik J, Zeroual Y, Dzairi FZ, Talbi M, Blaghen M. 2000. Waste water bacteria resistant to heavy metals and antibiotics. Current Microbiol. 41(2000): 151-156. doi: 10.1007/s002840010109.

Ge HW, Lian MF, Wen FZ, Yun YF, Jian FY, Ming T. 2009. Isolation and characterization of the heavy metal resistant bacteria CCNWRS33-2 isolated from root nodule of Lezpedesa cuneata in gold mine tailings in China. J Hazard Mater. 162(1): 50-56. doi: 10.1016/j.jhazmat.2008.05.040.

Gusten WM, Hansen EA, Cunha BA. 2002. Acinetobacter baumannii pseudomeningitis. Heart Lung 31(1): 76-78.

Georgopoulus PG, Roy A, Opiekun RE, Yonone-Lioy MJ, Lioy PJ. 2001. Environmental copper : its dynamics and human exposure issues. J Toxicol Environ Health B Crit Rev. 4(4): 341-94. doi: 10.1080/109374001753146207

Hiniker A, Collet JF, Bardwell JC. 2005. Copper stress causes an in vivo requirement for the Eschericia coli disulfide isomerase DsbC. J Biol Chem. 280(40): 33785-33791. doi: 10.1074/jbc.M505742200.

Irawati W, Yuwono T, Hartiko H, Soedarsono J. 2002. Isolasi dan karakterisasi bakteri resisten tembaga dari limbah industri [Isolation and characterization of copperresistant bacteria from industrial sewage]. Berkala Biol. 2(13): 785-792.

Irawati W, Yuwono T, Hartiko H, Soedarsono J. 2003. Accumulation of copper-resistant bacteria isolated from industrial sewage. Indones J Biotech. p650-656.

Jawad A, Snelling AM, Heritage J, Hawkey PM. 2004. Exceptional desiccation tolerance of Acinetobacter radioresistens. J Hosp Infect. 39(3): 235-240. doi: 10.1016/S0195-6701(98)90263-8.

Kunito T, Nagaoka K, Tada N, Saeki K, Senoo K,Oyaizu H, Matsumoto S. 1997. Characterization of Cu-resistant Bacterial Communities in Cu Contaminated Soils. Soil Sci Nutri. 43(3):709-717. doi: 10.1080/00380768.1997. 10414795.

Malik A. 2004. Metal bioremediation through growing cells. Environ Int. 30(2): 261-278. doi: 10.1016/j.envint .2003 .0

Macomber L, Rensing C, Imlay JA. 2007. Intracellular copper does not catalyze the formation of oxidative DNA damage in Escherichia coli. J Bacteriol. 189(5):1616-1626. doi: 10.1128/JB.01357-06.

Macomber L, Imlay JA. 2009. The iron-sulfur clusters of dehydratases are primary intracellular targets of copper toxicity. Proc Natl Acad Sci U.S.A. 106(20): 83448349. doi: 10.1073/pnas.0812808106.

Magnani D, Barre O. Gerber SD, Solioz M. 2008. Characterization of the CopR regulon of Lactococcus lactis IL 1403. J Bacteriol. 190(2): 536-545. doi: 10.1128/JB.01481-07.

Mergeay M, Monchy S, Vallaeys T, Auquier V, Benotmane A, Bertin P, Taghavi S, Dunn J, van der Lelie D, Wattiez R. 2003. Ralstonia metallidurans, a bacterium specifically adapted to toxic metals: towards a catalogue of metalresponsive genes. FEMS Microbiol Rev. 27(2-3): 385-410. doi: 10.1016/S01686445(03)00045-7.

Osman D, Cavet JS. 2008. Copper homeostatis in bacteria. Adv Appl Microbiol. 65: 217-247. doi: 10.1016/S00652164(08)00608-4.

Pal A, Paul AK. 2010. Nickel uptake and intracellular localization in Cupriavidus pauculus KPS 201, native to ultramatic ecosystem. Adv Biosci Biotech. 1:276280. doi: 10.4236/abb.2010.1403. 6

Piotrowska-Seget Z, Cynon N, Kozdroj J. 2005. Metaltolerant bacteria occurring in heavily polluted soil and mine spoil. Appl Soil Ecol. 28(3): 237-246. doi: 10.1016/j.apsoil.2004.08.001.

Puig S, Rees AM, Dennis JT. 2002. The ABCDs of periplasmic copper trafficking. Structure 10(10): 1292-1295. doi: 10.1016/S0969-2126(02)00863-8.

Raja CE, Anbazhagan K, Selvam GS. 2006. Isolation and characterization of a metalresistant Pseudomonas aeruginosa strain. World J Microbiol Biotech. 22(6):577-586. doi: 10.1007/s11274-005-9074-4.

Rouch DJ, Camakaris J, Lee BTO, Luke RK. 1985. Inducible Plasmid Mediated Copper Resistance in Escherichia coli. J Gen Microbiol. 131(4): 939-943. doi: 10.1099/00221287-131-4-939. 
Shakoori AR, Muneer B. 2002. Copper resistant bacteria from industrial effluents and their role in remediation of heavy metals in wastewater. Folia Microbiol. 47(1): 4350. doi: 10.1007/BF02818564.

Saxena D, Joshi N, Srivastava S. 2002. Mechanism of copper resistance in a copper mine isolate Pseudomonas putida strain S4. Current Microbiol. 45(6): 410-414. doi: 10.1007/s00284-002-3787-5.

Simor AE, Lee M, Vearncombe M, Jones-Paul L, Barry C, Gomez M, Fish JS, Cartotto RC, Palmer R, Louie M. 2002. An outbreak due to multiresistant Acinetobacter baumannii in a burn unit: risk factors for acquisition and management. Infect Control Hosp Epidemiol. 23(5): 261-267. doi: 10.1086/502046.

Tindall BJ, Rosello-Mora R, Busse HJ, Ludwig W, Kampfer P. 2010. Notes on the characterization of prokaryote strains for taxonomic purposes. Int $\mathrm{J}$ Syst Evol Microbiol. 60(1): 249-266. doi: 10.1099/ijs.0.016949-0.

Waldron KJ, Robinson NJ. 2009. How do bacterial cells ensure that metalloproteins get the correct metal? Nat Rev Microbiol. 7(2): 25-35. doi:10.1038/nrmicro2074.

Yong JP, Jae JK, SLY, Eun YL, So JK, Sung WK, Byung CL, Seog KK. 2008. Enhancement of bioremediation by Ralstonia sp. HM-1 in sediment polluted by Cd and Zn. Bioresour Technol. 99(16): 7458-7463. doi: 10.1016/j.biortech.2008.02.024.

Zaki S, Farag S. 2010. Isolation and molecular characterization of some copper biosorped strains. Int J Environ Sci Tech. 7(3):533-560.

Zyskind JW, Bernstein SI. 1992. Recombinant DNA Laboratory Manual. New York : Academy Press, Inc. 